\author{
Ана С. Батас \\ Универзитет у Београду \\ Филолошки факултет \\ Катедра за српски језик \\ с јужнословенским језицима
}

https://doi.org/10.18485/ai_fonefonosj.2020.ch3

$811.163 .41 ' 342.2$

\title{
СПЕКТРАЛНЕ КАРАКТЕРИСТИКЕ (ПРЕТ)ПАЛАТАЛНИХ ФРИКАТИВА И АФРИКАТА У СРПСКОМ ЈЕЗИКУ: ПРЕЛИМИНАРНИ НАЛАЗИ
}

У раду се бавимо претпалаталним фрикативима и африкатама у српском језику. На основу резултата артикулационих испитивања Б. Милетића, закључујемо да гласови који се традиционално сврставају у „тврде” палаталне фрикативе и африкате не заузимају то место у савременим класификацијама заснованим на месту изговора. На основу акустичких испитивања говорника којима је српски матерњи, закључујемо да нема разлике у целокупном трајању ових фрикатива и африката. Постоје пак незанемарљиве међусубјекатске варијације у центроидној фреквенцији и висини спектралних врхунаца.

Кључне речи: претпалатални, фрикативи, африкате, српски језик

anabatas@fil.bg.ac.rs

** Овај рад настао је у оквиру пројекта „Српски језик и његови ресурси: теорија, опис и примене” (178006), који финансира Министарство просвете, науке и технолошког развоја Републике Србије. 


\section{Увод}

1. Роман Јакобсон свакако није први лингвиста који је закључио да између артикулационих и акустичких појава не мора постојати апсолутни паралелизам, али је први детаљно показао на бројним примерима да то не мора бити случај и да се различитим покретима различитих говорних органа могу произвести сличне (или чак исте појаве) (Јакобсон 1986: 30- 33). Полазећи управо од те претпоставке, у исту групу фонема сврстао је, на пример, оне које се изговарају у периферним деловима усне дупље - било на почетку, било на крају - и приписао им обележје [+дифузност] (Јакобсон et al. 1963). Такве фонеме на акустичком плану карактерише појава форманата распршених по спектру, а исто важи и за оне које уместо форманата имају шум.

Па ипак, од Р. Јакобсона до данас у бројним радовима настоје се одредити корелати артикулационих покрета и акустичких сигнала. Тако се, на пример, прате кретања вокалских транзиција иза или испред консонанта и доводе се у везу са местом артикулације консонанта (Хале et al. 1957, а за српски језик в. Симић - Симић 1980), док се висина антиформанта код назалних сонаната доводи у везу са њиховим местом артикулације (Риц - Јонгман 2009: 195). На крају, тиме се бави и изузетно утицајна квантална теорија К. Н. Стивенса (Стивенс 1972). У њој се полази од експериментално више пута утврђене чињенице да некад и најмањи покрет говорних органа може произвести веома велике (скоковите) разлике у домену акустике.

Ми свакако прихватамо Јакобсонове аргументе да нема апсолутног паралелизма између артикулационих и акустичких појава, али сматрамо да би било пожељно да фонетска испитивања имају циљ да резултате добијене 
методама акустичке фонетике протумаче и из угла артикулационе фонетике (фонологије, аудитивне перцепције).

Познато је да од Милетићевих описа артикулације гласова српског језика, насталих на основу палатографских испитивања у првим деценијама двадесетог века (Милетић 1933), нема новијих испитивања овог типа. За време у које су спроведена, његова испитивања била су изузетно модерна, а до данас су се задржала у приручницима из фонетике и фонологије. У савременим научним студијама истраживачи покушавају да на основу Милетићевих описа и илустрација да прецизније одреде место артикулације (Милер - Зец 2003). Следе описи Б. Милетића са нашим подвлачењем.

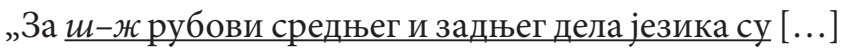
уздигнути те остављају на средини жлеб. Врх језика уздигнут је такође ка алвеолама, тако да се између његове доње површине и предњих зуба ствара мања дупља: истовремено се и усне истурају градећи другу дупљу између спољне стране секутића и унутрашње стране усана; спајањем обе дупље ствара се у предњем делу уста сразмерно велики резонатор ('котлић') са малим отвором (јер су усне и заобљене), што такође доприноси ниском тембру ових гласова [...]" (Милетић 1952: 32-34)

„При грађењу $u-u(=m w, \partial ж)$ дише се врх језика ка предњим и средњим алвеолама, где ивица чини преграду. Између доње површине језика и унутрашње стране секутића ствара се резонатор карактеристичан за све шуштаве гласове и у једном тренутку када се преграда отвара прелази језик у положај за $\underline{w-\nVdash . ~ У с н е ~ с у ~ з а о б љ е н е ~ и ~ и с т у р е н е ~(н е ш т о ~ ј а ч е ~ н е г о ~}$ при $\mathcal{u}-\nVdash$ ) и акустички утисак ('тврдоћа') ових гласова зависи у првом реду од артикулације усана. Ч 
је безвучно, а ц звучно. Ови гласови не изговарају се на целом подручју нашег језика једнако, већ негде 'тврђе', а негде 'мекше' (у правцу ћ - ђ).' (Милетић 1952: 42-43)

С обзиром на то да се врх језика (апекс) и код фрикатива и код африката уздиже ка алвеолама, односно, прецизније, ка предњим и средњим алвеолама, можемо са сигурношћу рећи да ови гласови нису палатални (предњонепчани), већ спадају у неку групу гласова која се изговара пред предњим непцем: посталвеоларни (палатоалвеоларни), ретрофлексни или алвеопалатални ${ }^{1}$. Такве гласове убрајамо у „претпалаталне” - оне који се изговарају испред палатума - што не одговара традиционалном значењу тог термина, према којем је „претпалатални” синониман „алвеопалаталном”.

У неким једноставним случајевима, када се гласови изговарају на месту на којем нема простора за велике варијације, описи Б. Милетића сасвим су довољни и за данашње стандарде у артикулационој фонологији. Међутим, то није увек случај и тада се јављају следећи проблеми.

(1) Говорни орган који се некада сматрао недељивим у међувремену се почео сматрати низом више различитих говорних органа;

(2) За неке гласове се показало да је динамични опис бољи од статичног;

(3) Нема довољно података о дијалекатском пореклу испитаника.

На први проблем наилазимо управо код гласова које Б. Милетић убраја у палаталне фрикативе и африкате. Данас се ти гласови деле на више група: посталвеолар-

1 Детаљније о класификацији претпалаталних гласова в. Рекасенс 2013, 2014, Китинг 1988, 1991, Китинг - Лахири 1993. 
ни (палатоалвеоларни), алвеопалатални и палатални. А када овој подели додамо и покретни артикулатор, добијамо још и апикалне, ламиналне и дорсалне; и ретрофлексне. На крају, ако поред примарног места артикулације посматрамо и секундарно, морамо додати и групу палатализованих. Тумачећи Милетићеве описе, различити аутори долазе до потпуно различитих закључака, па има оних који сматрају се српски гласови /š/, /ž/, /č/ и /dž/ убрајају у ретрофлексне (Китинг - Лахири 1993), и оних који их сматрају палатоалвеоларним (Зец - Милер 2003).

Други проблем се везује за статичку природу описа африката. Милетић је настојао да опише покрет који језик прави у различитим фазама артикулације, али ми ипак сматрамо да метода палатографије (уместо савремене методе електропалатографије) није могла дати прецизне податке о положајима говорних органа праћених у времену. Из тог разлога је тешко рећи да ли су претпалаталне африкате у српском језику хоморгане или не.

Трећи проблем је у вези са варијантношћу гласова условљеном дијалекатским факторима (Р. Симић и Б. Остојић (1996) користе појам „дијафон”). Из дијалектолошких радова сазнајемо да се у бачким (и банатским) говорима јавља „шуштавија” варијанта. Р. Симић и Б. Остојић (idem) приказују ову варијанту као бемолну (лабијализовану) ${ }^{2}$. Није нам познато да ли је Б. Милетић имао испитаника из тих крајева, а то би могло значајно да утиче на резултате испитивања. Приметио је да постоје варијанте различите тврдоће за африкате (Милетић 1952: 43), али нема таквог податка за фрикативе.

2 У раду се нећемо бавити даље овом варијантом. Сматрамо је пак ретрофлексном и свакако лабијализованом. 
2. Акустичке карактеристике опструената угрубо би се могле поделити на квантитативне - оне које се односе на трајање сегмената, и спектралне - оне које се односе на фреквенцију (и јачину) ${ }^{3}$. Овде ћемо се пре свега бавити спектралним карактеристикама ове групе гласова - описом изгледа шума на спектрограмима, утврђивањем спектралног врхунца и мерењем центроидне фреквенције (тежишне фреквенције спектра), а један мањи део рада посветићемо квантитативним карактеристикама.

Испитивали смо шест информатора којима је српски језик матерњи. Информатори су по четири пута изговарали сваки пример у оквирним реченицама: „Реци : опет ”. Снимали смо их професионалном опремом у просторији са смањеном реверберацијом на Филолошком факултету Универзитета у Београду. Сви информатори су из шумадијско-војвођанског дијалекта, али ниједан није из банатско-бачких говора.

За разлику од претходних испитивања у Praat-y, процедуру којом анализирамо податке значајно смо формализовали. Све звучне сигнале филтрирали смо филтром на $500 \mathrm{~Hz}$, којим смо уклонили све ниже фреквенције. Средишњу тачку у трајању гласа одређивао је са̂м програм помоћу скрипта који смо за ову прилику направили. На том месту је прављен спектрални одсечак, а рачунати су спектрални врхунци и центроидна фреквенција.

3 Овај рад се надовезује на низ претходних радова: Батас 2007, 2010,2013 . и 2014. Трајањем опструената најдетаљније смо се бавили у Батас 2013. Овде ћемо пак испитивати међусобно трајање претпалаталних фрикатива и африката, па се радови у том погледу надовезују један на други, али се не преклапају. 


\section{Резултати}

\section{1. Апикално-претпалатални фрикативи}

С. Гудурић и Д. Петровић (2008: 88-93) утврђују да „звучна греда"4 постоји на спектрограмима код звучних палаталних фрикатива, како их они посматрају, а да је код безвучних палаталних фрикатива нема. Р. Симић и Б. Остојић (1996: 188-189) истичу да је турбулентни шум апикално-палаталних фрикатива нижи од шума денталних. О спуштању тона ${ }^{5}$ код палаталних фрикатива у односу на денталне пишу и Гудурић - Петровић 2008: 90.

На слици бр. 1 налази се спектрограм речи „каша”, у којој се безвучни апикално-претпалатални фрикатив нашао у интервокалској позицији - између два вокала /a/. Овај спектрограм илуструје типичну реализацију овог фрикатива ${ }^{6}$. Његов шум креће са фреквенција око 1800-2000 Hz. Мерење почетка шума на спектрограмима није прецизна метода, зато што зависи, између осталог, од подешавања у Praat-у. Ако се изабере нижи динамички опсег, региструју се шумови мањег интензитета; и обрнуто, ако се изабере виши динамички опсег, региструју се само шумови већег интензитета, што као последицу има фрикативни шум који полази са виших фреквенција.

4 С. Гудурић у бројним радовима користи термин „звучна греда”. У неким радовима смо користили и термин „звучна црта” или „звучна линија”, али је ниједан од њих још није усталио. На енглеском је термин ,voice bar”.

5 Прецизније би се могло рећи - „шума”.

6 У претходним испитивањима утврдили смо које су типичне реализације ове фонеме (в. Батас 2007, 2014). 


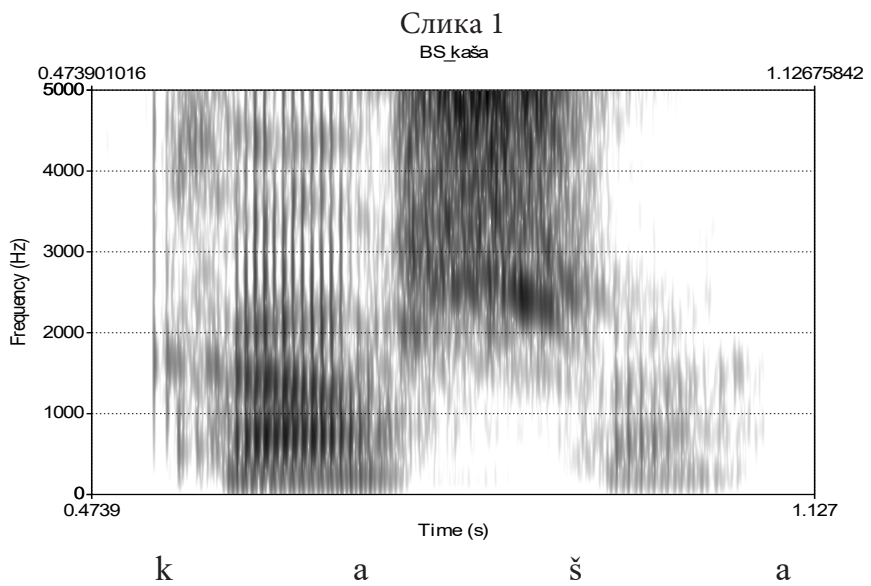

Уместо одређивања најниже фреквенције са које креће фрикативни шум, прецизније је посматрати шум (упросечених) спектралних одсечака (в. слику 2).

Слика 2

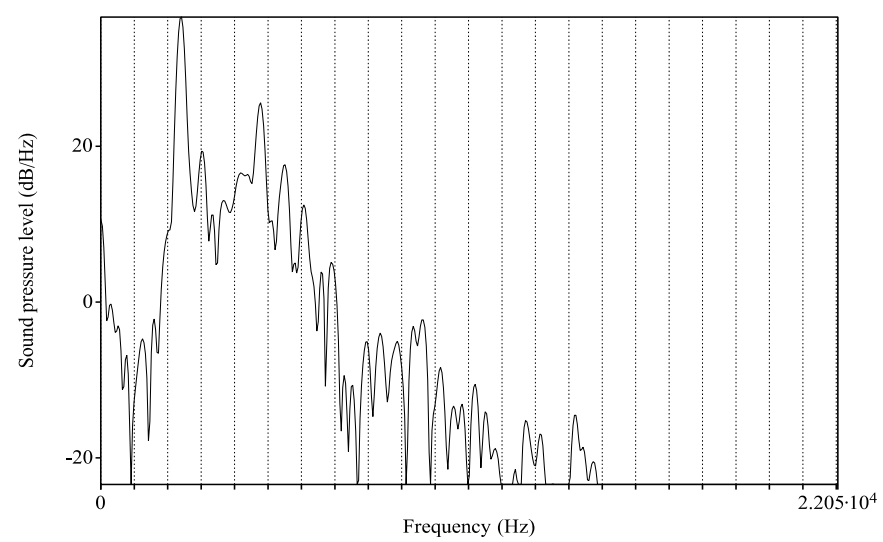

За претпалаталне фрикативе и африкате карактеристично је да се облик спектралног шума мења у за- 
висности од говорника. Из тог разлога веома је тешко говорити о типичним реализацијама. У једној варијанти - први врхунац налази се на око $2500 \mathrm{~Hz}$, а други на око $5000 \mathrm{~Hz}$. У другој варијанти - нема нижег врхунца, већ се први и једини налази између 4000 и 5000 Hz. Слично изгледају у спектри остала три гласа, само што се код звучних јавља, наравно, ефекат рада гласних жица у виду нископропусних фреквенција.

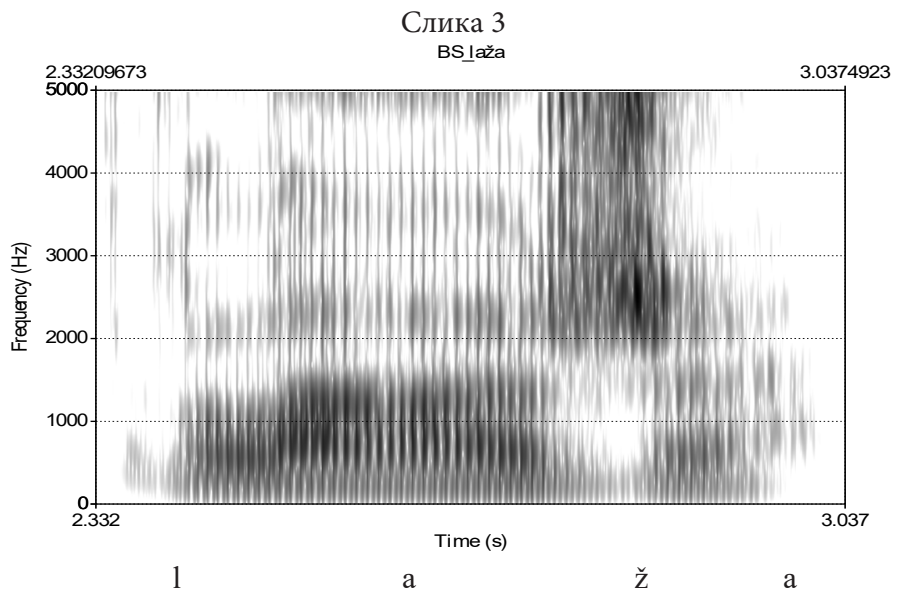

На слици бр. 3 налази се звучни апикално-претпалатални фрикатив /ž/. Фрикативни шум је често у целини праћен тоном када се фрикатив реализује у интервокалској позицији. Присуство тона се види и на основу „звучне греде” у доњем делу спектрограма и на основу глоталних импулса (вертикалних танких линија) дуж целог шума. Као и код безвучног парњака, шум почиње на висини од 1800-2000 Hz, али је тај податак непрецизан, будући да зависи од параметара мерења, што смо раније већ истакли. 


\section{2. Апикално-претпалаталне африкате}

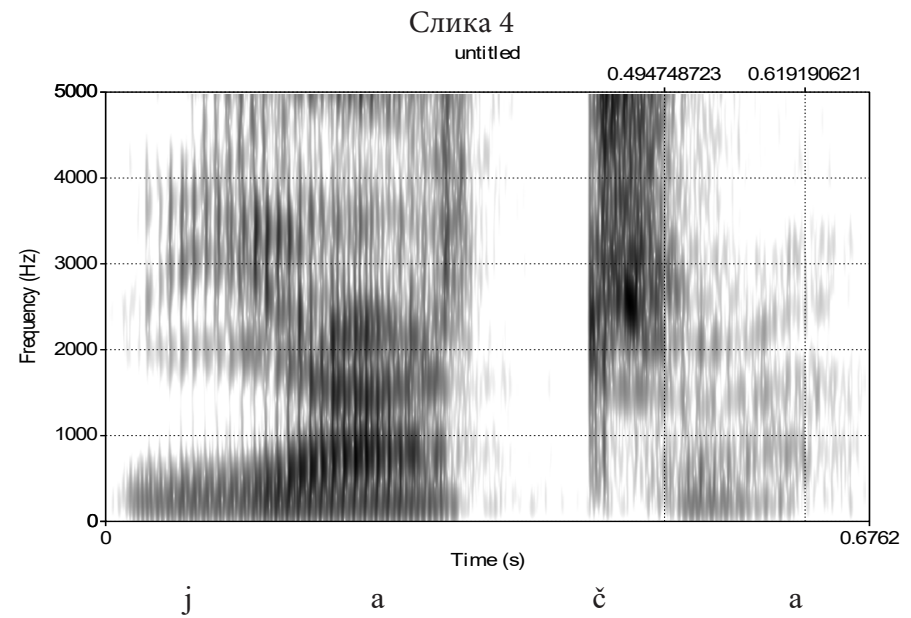

Како се са слике бр. 4 може видети, безвучна апикално-претпалатална афиката започиње паузом, пошто се поклапа са фазом оклузије на артикулационом плану, што је општепозната фонетска чињеница. Одмах по отпуштању препреке види се танак шум експлозије. За њим следи кратак фрикативни шум. Од 1957. године и чувене дисертације Л. Гертсмана (1957) поставља се питање шта на перцептивном плану разликује африкате од фрикатива - да ли је то краће време пораста амплитуде или краће трајање фрикативног шума код африката. К. Клуендер и М. Волш закључују да се африкате од фрикатива ипак у перцептивном погледу разликују пре свега због краћег трајања фрикативног шума (Клуендер - Волш 1992).

Осим што је фрикативни шум код африката краћи него код фрикатива, на спектрограмима међу њима нема посебне разлике (уп. слике 4 и 1). 
Следећом сликом илуструјемо глас /dž/ у интервокалском положају. До краја африкате „звучна греда” постаје блеђа чак и интевокалском положају. Остали елементи шума звучног парњака личе на безвучни.

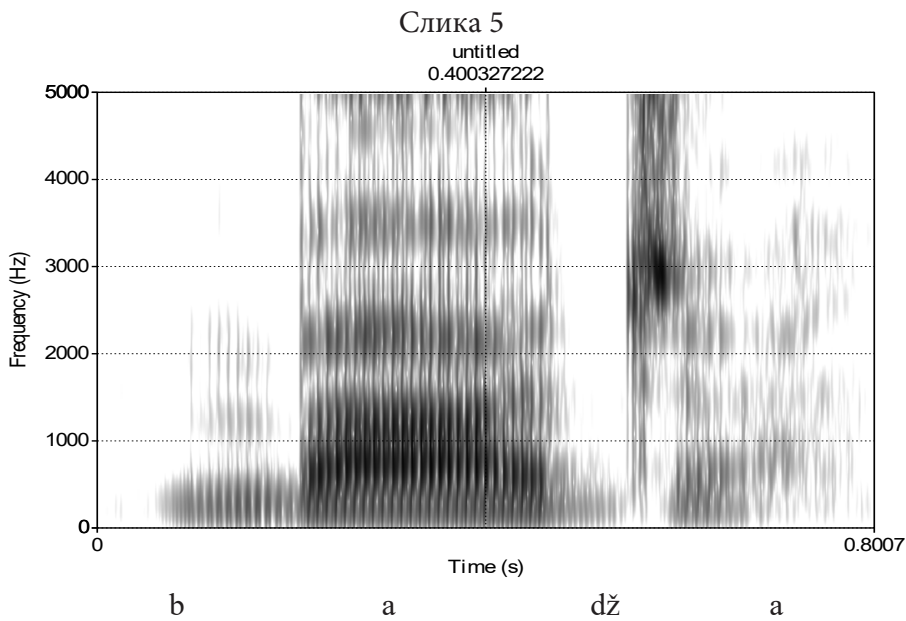

\section{3. Квантитативни подаци}

У табели бр. 1 представљамо резултате мерења трајања за четири претпалатална гласа изговорена од стране шест говорника (сваки говорник је четири пута изговарао).

Табела 1

\begin{tabular}{|c|c|c|c|c|}
\hline \multirow{2}{*}{ Гласови } & \multirow{2}{*}{$\begin{array}{c}\text { Просек } \\
{[\mathrm{ms}]}\end{array}$} & \multirow{2}{*}{$\begin{array}{c}\text { Ст. дев. } \\
{[\mathrm{ms}]}\end{array}$} & \multicolumn{2}{|c|}{ Ниво поверења 95\% } \\
\cline { 4 - 5 } & Доња граница & Горња граница \\
\hline$/ \check{s} /$ & 161,17 & 11,78 & 130,88 & 191,46 \\
\hline$/ \check{c} /$ & 108,92 & 9,60 & 84,23 & 133,60 \\
\hline$/ \mathrm{d} z ̌ /$ & 110,00 & 9,20 & 86,34 & 202,28 \\
\hline
\end{tabular}


Између фрикатива и африката нема статистички значајне разлике у трајању. Једино безвучни парњаци трају дуже од звучних, што смо већ више пута утврдили (Батас 2013, 2014). У раду из 2013. закључили смо да када се као фактор изабере начин артикулације, међу овим гласовима постоји разлика у трајању, што је показано анализом варијансе $(\mathrm{F}=8,216, \mathrm{df}=2, \mathrm{p}=0,004)$. Међутим, само експлозив [t] траје значајно краће од друга два гласа, док се фрикатив [s] и африката [ts] у интервокалском положају не разликују по трајању (разлика у просецима $=-1,111 \mathrm{~ms}$, станд. грешка $=5,381, \mathrm{p}$ =1) (Батас 2013).

У следећој табели представљамо резултате мерења висине највишег спектралног врхунца за четири претпалатална гласа изговорена од стране шест говорника (сваки говорник је четири пута изговарао).

Табела 2

\begin{tabular}{|c|c|c|c|c|}
\hline \multirow{2}{*}{ Гласови } & \multirow{2}{*}{$\begin{array}{c}\text { Просек } \\
{[\mathrm{Hz}]}\end{array}$} & \multirow{2}{*}{$\begin{array}{c}\text { Ст. дев. } \\
{[\mathrm{Hz}]}\end{array}$} & \multicolumn{2}{|c|}{ Ниво поверења 95\% } \\
\hline & & & Доња граница & Горња граница \\
\hline /šl & 3401,94 & 142,46 & 3035,73 & 3768,16 \\
\hline$|\check{\mathbf{z}}|$ & 3428,00 & 252,85 & 2778,02 & 4077,97 \\
\hline |čc/ & 3755,29 & 180,94 & 3290,17 & 4220,42 \\
\hline /dž/ & 3882,78 & 364,19 & 2946,59 & 4818,97 \\
\hline
\end{tabular}

Међу њима нема статистички значајне разлике.

Следећом табелом представљамо резултате мерења висине центроидне фреквенције за четири претпалатална гласа изговорена од стране шест говорника (сваки говорник је четири пута изговарао). 
Табела 3

\begin{tabular}{|c|c|c|c|c|}
\hline \multirow[b]{2}{*}{ Гласови } & \multirow[b]{2}{*}{ Просек [Hz] } & \multirow{2}{*}{$\begin{array}{c}\text { Ст. дев. } \\
{[\mathrm{Hz}]}\end{array}$} & \multicolumn{2}{|c|}{ Ниво поверења 95\% } \\
\hline & & & Доња граница & $\begin{array}{c}\text { Горња } \\
\text { граница }\end{array}$ \\
\hline /šs $/$ & 3950,08 & 156,89 & 3546,80 & 4353,37 \\
\hline $\mid \check{z} /$ & 3869,17 & 173,34 & 3423,58 & 4314,79 \\
\hline$|\check{c}|$ & 4089,50 & 170,70 & 3650,70 & 4528,30 \\
\hline /dž/ & 4127,38 & 349,78 & 3228,23 & 5026,52 \\
\hline
\end{tabular}

Ни међу њима нема статистички значајне разлике.

Центроидна фреквенција често се узима као дискриминативни фактор међу фрикативима и африкатама који се разликују по месту изговора (в. Гордон et al. 2002). Међутим, то није увек случај. У раду Зигис et al. 2012 испитују се безвучна палатоалвеоларна африката, каква се изговара у чешком, и безвучна ретрофлексна, каква се изговара у пољском. На основу испитивања центроидне фреквенције закључено је да се међу овим варијантама нема статистички значајне разлике.

Пре него што би се за српски језик донели одговарајући закључци, сматрамо да би, због незанемарљивих варијација међу говорницима, требало проширити испитивање већим бројем информатора.

\section{Закључак}

Сматрамо да се на основу Милетићевих артикулационих испитивања гласова који се традиционално називају тврди палатални фрикативи и африкате може закључити да се, гледано из угла савремене артикулационе фонетике, изговарају испред предњег непца. Они не одговарају сасвим ни посталвеоларној (пала- 
тоалвеоларној варијанти), која је најчешће ламинална и палатализована, нити одговарају ретрофлексној варијанти, за коју претпостављамо да се изговара у банатско-бачким говорима.

Између претпалаталних фрикатива и афраката нема разлике у трајању, осим што безвучни парњаци трају дуже од својих звучних варајаната. Нема разлике ни у висини спектралног врхунца нити у висини центроидне фреквенције. Ипак, пре дошења коначних закључака, требало би спровести додатна истраживања.

\section{ЛИТЕРАТУРА}

Батас 2007: Ана Батас, Квантитативне и спектралне карактеристике консонаната српског књижевног језика, рукопис необјављеног магистарског рада, Београд: Филолошки факултет.

Батас 2013: Ана Батас, „Трајање консонаната у интервокалском положају", Научни састанак слависта у Вукове дане, 42/3,139-152.

Батас 2014: Ана Батас, Фонетске и акиенатске промене речи

у континуалном говору, рукопис необјављене докторске дисертације, Београд: Филолошки факултет.

Гертсман 1957: L. J. Gerstman, „Perceptual dimensions for the friction portions of certain speech sounds", Unpublished doctoral dissertation, New York University.

Гордон et al. 2002: Matthew Gordon, Paul Barthmaier, Kathy Sands, „A cross-linguistic acoustic study of voiceless fricatives", Journal of the International Phonetic Association, $32 / 2,141-174$.

Зигис et al. 2012: Marzena Zygis, Daniel Pape, Luis M. T. Jesus, ,(Non-)retroflex Slavic affricates and their motivation:

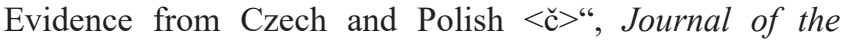
International Phonetic Association, 42/3, 281-329.

Јакобсон 1986: Роман Јакобсон, Шест предавања о звуку и значењу, Нови Сад: Књижевна заједница Новог Сада. 
Јакобсон et al. 1963: Roman Jakobson, Gunnar Fant, Morris Halle, Preliminaries to Speech Analysis: The Distinctive Features and Their Correlates. $2^{\text {nd }}$ edition. MIT, Acoustics Lab., Technical Report No. 13, 1963 [1952].

Китинг - Лахири 1993: Patricia Keating, Aditi Lahiri, „Fronted velars, palatalized velar and palatals", Phonetica, 50, 73-101. Китинг 1988: Patricia Keating, „Palatals as complex segments: X-ray evidence", UCLA Working Papers in Phonetics, 69, 77-91.

Китинг 1991: Patricia Keating, „Coronal places of articulation”, [in:] Carole Paradis, Jean-François Prunet (eds.), The Special Status of Coronals: Internal and External Evidence., San Diego, CA: Academic Press, 29-48.

Клуендер - Волш 1992: Keith R. Kluender, Margaret A. Walsh, „Amplitude rise time and the perception of the voiceless affricate/fricative distinction", Perception and Psychophysics 51/4, 328-333.

Милер - Зец 2003: Amanda Miller-Ockhuizen, Draga Zec, „Phonetics and phonology of contrastive palatal affricates", Working Papers of the Cornell Phonetics Laboratory, 15, 130-193. Милетић 1933: Branko Miletić, Izgovor srpskohrvatskih glasova, Beograd, Izdanje zadužbine Milana Kujundžića.

Милетић 1952: Бранко Милетић, Основи фонетике српског језика, Београд: „Знање” - предузеће за уџбенике Народне Републике Србије.

Рекасенс 2013: Daniel Recasens, „On the articulatory classification of (alveolo)palatal consonants", Journal of the International Phonetic Association, 43, 1-23.

Рекасенс 2014: Daniel Recasens, „Acoustic and coarticulatory characteristics of (alveolo)palatal stop consonants, and velar softening“, Journal of Phonetics, 42, 37-51.

Риц - Јонгман 2009: Henning Reetz, Allard Jongman, Phonetics, Transcription, Production, Acoustics, and Perception, WilleyBlackwell.

Симић - Симић 1980: Brigit Simić i Radoje Simić, „Sistem afrikata u srpskohrvatskom književnom jeziku”, Književni jezik, Sarajevo, IX/2, 7-21.

Стивенс 1972: Kenneth Stevens, „The quantal nature of speech: Evidence from Articulatory-Acoustic data“, In: E.E. David \& 
P.B. Denes (eds.) Human Communication: A Unified View.

New York: McGraw-Hill, 51-66.

Хале et al. 1957: M. Halle, G. W. Hughes, J. P. A. Radley, „Acoustic properties of stop consonants", Journal of the Acoustical Society of America, 29, 107-116.

Ana. S. Batas

\author{
SPECTRAL CHARACTERISTICS \\ OF THE PRE-PALATAL FRICATIVES \\ AND AFFRICATES IN THE SERBIAN LANGUAGE: \\ PRELIMINARY FINDINGS
}

\title{
Summary
}

In this paper the author examines the apical fricatives and affricates in the Serbian language which are pronounced in front of the hard palate. The term "pre-palatal" is not used in the traditional sense, which is synonymous with the term "alveolopalatals", but rather for all places of articulation between the alveolar ridge and the hard palate (postalveolar/palato-alveolar, alveolo-palatal, retroflex). According to B. Miletić these sounds are produced on the hard palate, but his findings are not in agreement with the modern approach to articulatory phonetics. In our experimental study, based on the acoustic measurements for six Serbian speakers, no difference was found between fricative and affricate durations in the intervocalic positions. There are significant intrasubject differences for measurements of center of gravity and spectral peaks.

Key-words: pre-palatals, fricatives, affricates, Serbian language 